\title{
Genetic variation related to caffeine metabolism or response during exercise
}

\author{
Nanci S Guest ${ }^{1 *}$, Joseph Jamnik¹, Christopher Womack², Ahmed El-Sohemy ${ }^{1}$ \\ From The Twelfth International Society of Sports Nutrition (ISSN) Conference and Expo \\ Austin, TX, USA. 11-13 June 2015
}

\section{Background}

Caffeine use for improved athletic performance has variable effects. Caffeine can exert a wide variety of physiologic effects that range from adverse (e.g., anxiety, increased heart rate, nervousness) to pleasurable (e.g., alertness, elevated mood, increased energy), which could be associated with individual genetic differences.

\section{Methods}

We examined whether a panel of 25 SNPs in 19 genes that might be related to caffeine metabolism or response modified exercise performance, or were associated with any physiologic outcomes during exercise. Subjects were trained male cyclists $(n=33)$ who underwent a doubleblind placebo-controlled crossover trial to test the effects of caffeine $(6 \mathrm{mg} / \mathrm{kg})$ on various performance parameters during a computer-simulated $40 \mathrm{~km}$ time trial. The 25 SNPs were genotyped using the Sequenom MassARRAY ${ }^{\circledR}$ system, and caffeine-genotype interactions on time trial time, $\mathrm{VO}_{2} \max$, heart rate, respiratory exchange ratio and rate of perceived exertion were assessed using repeated measures analysis of variance.

\section{Results}

There was a significant interaction between caffeine and rs4410790, a SNP located near the aryl hydrocarbon receptor $(A H R)$ gene, on heart rate during the time trial $(\mathrm{p}=0.007)$. Compared with placebo, caffeine supplementation increased heart rate (HR) to a greater extent in carriers of the $\mathrm{T}$ allele $(\mathrm{n}=19$; placebo $=155 \pm 12$ bpm; caffeine $=165 \pm 11 \mathrm{bpm} \mathrm{p}=<0.0001)$ compared with CC homozygotes $(\mathrm{n}=14$; placebo $=164 \pm 15 \mathrm{bpm}$; caffeine $167 \pm 14 \mathrm{bpm} \mathrm{p}=0.11)$.

${ }^{1}$ Faculty of Medicine, Department of Nutritional Sciences, University of Toronto, Toronto, ON, M5S 3E2, Canada

Full list of author information is available at the end of the article

\section{Conclusion}

Our findings show that a polymorphism near the $A H R$ gene was associated with a greater elevation in HR during a 40-kilometer time trial after caffeine ingestion, but had no effect on performance.

\section{Authors' details}

${ }^{1}$ Faculty of Medicine, Department of Nutritional Sciences, University of Toronto, Toronto, ON, M5S 3E2, Canada. ²Department of Kinesiology, James Madison University, Harrisonburg, VA 22807, USA.

Published: 21 September 2015

doi:10.1186/1550-2783-12-S1-P53

Cite this article as: Guest et al.: Genetic variation related to caffeine metabolism or response during exercise. Journal of the International Society of Sports Nutrition 2015 12(Suppl 1):P53.

\section{Submit your next manuscript to BioMed Central and take full advantage of: \\ - Convenient online submission \\ - Thorough peer review \\ - No space constraints or color figure charges \\ - Immediate publication on acceptance \\ - Inclusion in PubMed, CAS, Scopus and Google Scholar \\ - Research which is freely available for redistribution

